\title{
Unit of Specific Volume
}

National Cancer Institute

\section{Source}

National Cancer Institute. Unit of Specific Volume. NCI Thesaurus. Code C69428.

An indication of the type of unit of measure being used to express a specific volume. 